RACAR : Revue d'art canadienne

Canadian Art Review

\title{
Turning the World Inside Out: Situating JR's Wish within Cultures of Participation
}

\section{Jennifer Orpana}

Volume 39, numéro 1, 2014

URI : https://id.erudit.org/iderudit/1026203ar

DOI : https://doi.org/10.7202/1026203ar

Aller au sommaire du numéro

\section{Éditeur(s)}

UAAC-AAUC (University Art Association of Canada | Association d'art des universités du Canada)

\section{ISSN}

0315-9906 (imprimé)

1918-4778 (numérique)

Découvrir la revue

\section{Citer cet article}

Orpana, J. (2014). Turning the World Inside Out: Situating JR's Wish within Cultures of Participation. RACAR : Revue d'art canadienne / Canadian Art Review, 39(1), 66-75. https://doi.org/10.7202/1026203ar
Résumé de l'article

En 2011, l'artiste de rue et photographe JR lance un défi à l'auditoire de la conférence TED : l'aider à la réalisation de son projet Inside Out en participant à des projets de montage de portraits publics qui viseront à générer un dialogue, susciter la sensibilisation, raconter des histoires ou rendre les communautés visibles. Trois ans plus tard, avec plus de 196,500 portraits affichés dans le monde entier, 902 actions de groupe et un flot constant de nouveaux projets publiés sur le site web et la page Facebook de Inside Out, ce phénomène mondial continue de croître. Cet article situe Inside Out parmi les cultures de participation qui ont émergé depuis les années 1990. De plus, il explique comment l'impact et les conséquences du néolibéralisme mondial ont contribué à établir les conditions dans lesquelles les actions de groupe de Inside Out peuvent se développer.
Tous droits réservés (C) UAAC-AAUC (University Art Association of Canada | Association d'art des universités du Canada), 2014
Ce document est protégé par la loi sur le droit d'auteur. L'utilisation des services d'Érudit (y compris la reproduction) est assujettie à sa politique d'utilisation que vous pouvez consulter en ligne.

https://apropos.erudit.org/fr/usagers/politique-dutilisation/ 


\section{Turning the World Inside Out: Situating JR's Wish within Cultures of Participation}

Jennifer Orpana, Western University. 20I 3 UAAC CONFERENCE Graduate STUdent essay aWard / PRIX POUR LE MEILleUr ESSAI PAR UN(E) DOCTORANT(E) AU CONGRÈS DE L'AAUC DE 2013

\section{Résumé}

En 20 I I, l'artiste de rue et photographe JR lance un défi à l'auditoire de la conférence TED : I'aider à la réalisation de son projet Inside Out en participant à des projets de montage de portraits publics qui viseront à générer un dialogue, susciter la sensibilisation, raconter des histoires ou rendre les communautés visibles. Trois ans plus tard, avec plus de 196,500 portraits affichés dans le monde entier, 902 actions de groupe et un flot constant de nouveaux projets publiés sur le site web et la page Facebook de Inside Out, ce phénomène mondial continue de croître. Cet article situe Inside Out parmi les cultures de participation qui ont émergé depuis les années 1990. De plus, il explique comment l'impact et les conséquences du néolibéralisme mondial ont contribué à établir les conditions dans lesquelles les actions de groupe de Inside Out peuvent se développer.

$\mathrm{I}$ , the organizers of the renowne gave a quasi-anonymous artist known by the initials "JR" an opportunity to "change the world" by granting him the prestigious TED Prize. ${ }^{1}$ TED is a non-profit organization that promotes innovative ideas in such fields as technology, education, and design. Every year, the TED Prize is presented to an individual who has the potential to develop an initiative that can "spark global change."2 Each TED Prize winner launches their innovative idea in a talk at the conference, which is filmed and posted on the TED website. ${ }^{3}$ By receiving this prize, JR joined the impressive roster of previous winners including Edward Burtynsky (2004), Bono (2005), Bill Clinton (2007), Sylvia Earle (2009), and Jamie Oliver (2010), whose TED Prize projects have addressed such causes as environmental issues, poverty in developing countries, and the rise of childhood obesity. ${ }^{4}$ As the winner of the prize, JR received $\$ 100,000$ and access to TED's vast resources and professional networks. ${ }^{5}$

In his talk, JR, donning sunglasses and a hat, begins by sharing his feelings about the daunting task presented to him through this opportunity. ${ }^{6}$ Charismatically, he muses on the enormity of "changing the world" in the face of significant social, political, and environmental crises. Framing his talk around the question, "Can art change the world," JR offers highlights from his impressive body of socially engaged work. His artistic practice mixes "art and action"7 using collaborative art, portrait photography, and street art techniques to draw attention to the lives of people in marginalized, or misrepresented, communities. Behind him, a slideshow flashes stunning images of his work, from his earlier experiments mixing photography and graffiti in the streets of Paris (Expo 2 Rue, 2001-04), to his recent, ambitious, wheatpaste poster projects that compose the 28 Millimeters series. This last series involved taking often highly animated, close-up portrait photographs of participants, reformatting the images into enormous black-and-white posters, and pasting them in sites that were meaningful to the subjects. JR has worked with a range of groups, including youth from a Paris housing project in Clichy-sous-Bois (Portrait of a Generation, 2004-06); people living in cities on both sides of the border wall separating Israel and Palestine (Face 2 Face, 2007; fig. 1); and women living in favelas and slums located in developing countries (Women Are Heroes, 2008-10). In his talk he draws on these examples to support his thesis that it is possible for art to change our perception of the world by starting conversations and addressing stereotypes through creative strategies that make people, and their causes, more visible. ${ }^{8}$

The wish that JR announces at the end of his talk is to launch the Inside Out Project (henceforth Inside Out), a global participatory art project that encourages people to embark on "group actions" inspired by his collaborative, often subversive artistic methods, with the help of an instructive website. ${ }^{9}$ It is JR's hope that by getting involved in Inside Out, participants will generate their own images, contributing to the production of knowledge and discourse, and, as he puts it, creating "something that the world will remember."10 In the three years since JR appealed to the TED audience to help him "turn the world Inside Out" by mounting their own public portrait projects to help generate dialogue, raise awareness, or tell stories, over 196,500 portraits have been displayed worldwide. ${ }^{11}$ For instance, in Toronto, the Manifesto Festival of Community and Culture pasted over 400 posters to celebrate the city's diversity and to speak out against cuts to arts funding. ${ }^{12}$ In North Dakota, the Lakota tribe used the Inside Out process to help spread the message that "We still exist" (2011).13 In Karachi, twentyfive Inside Out posters were mounted to raise awareness about religious persecution in Pakistan (2011). ${ }^{14}$ Inside Out has been used to "kick out violence" in Luanda (2013), 15 to fight for LGBT rights at the Russian Embassy in Berlin (2011), ${ }^{16}$ and to help the efforts to "Save the Arctic" at the North Pole (2013). ${ }^{17}$ With over 902 group actions to date and a steady stream of new projects being posted on the Inside Out website and the project's Facebook page, this global phenomenon continues to grow.

The drive to make communities visible through JR's Inside Out Project is particularly evident in developed or democratic regions. ${ }^{18}$ To better understand the overwhelming popularity of Inside Out we must first situate JR's project within the rise of cultures of participation since the 1990s. Inside Out's visual strategy of using portrait photographs to represent individual and community identities is linked to wide-ranging 


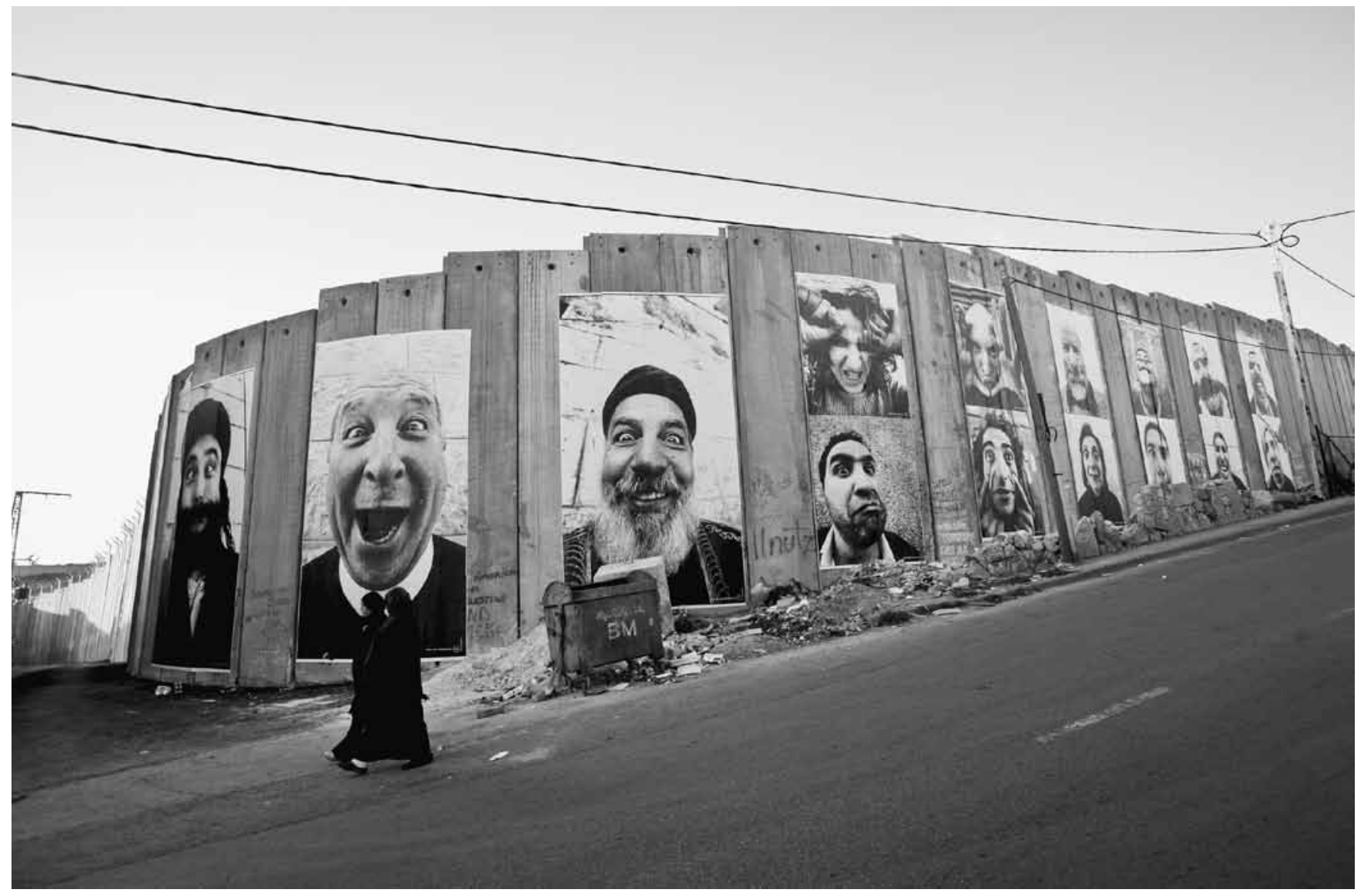

Figure I. JR, 28 Millimeters, Face2Face, Separation Wall, Palestinian Side in Bethlehem, March 2007 (Photo: JR, 2007).

developments in participatory art, visual research, and social media. Many leading scholars in participatory and collective art practices have related the rise of cultures of participation to the spread of global neoliberalism. ${ }^{19}$ For example, art scholar Grant Kester suggests that we consider the recent surge of art practices that visualize social networks or produce new forms of social interactions in terms of what it reveals about our current political moment, ${ }^{20}$ noting that the past two decades have not only seen the "rise of a powerful neoliberal economic order," but also a reinvigorated sense of "political renewal" in communities worldwide. ${ }^{21}$ These are the conditions in which Inside Out flourishes.

\section{Goals and Parameters of Inside Out}

As its website emphasizes, Inside Out is intended to be "the people's art project" and aspires to "transform messages of personal identity into art." 22 This process is accomplished through independently organized "group actions," which occur when people-photographers, activists, community organizers, so- cial workers, professors, students, and so on-use the resources available through the website to mount their own large, blackand-white photographic portrait posters in the name of an important cause. 23 Participants must not only have the conceptual and artistic skills to develop a statement and take photographs, but also a range of other professional skills similar to those of community outreach workers and arts managers in the not-forprofit sector. For example, each group must administer all stages of their group action, including recruiting the participants, acquiring photo permissions, selecting sites for the posters, collecting the materials needed to mount the posters, and in some cases, fundraising in order to pay the suggested donation of $\$ 20$ USD per poster. Importantly, while donations help to fund the project, the total amount may be adjusted or waived if a group cannot secure the funds. ${ }^{24}$

Once a group uploads a statement and a set of photographic portraits to the website, the Inside Out team converts the images to black and white and prints 36-inch by 53 -inch portrait posters, which are then sent back to the group to be 


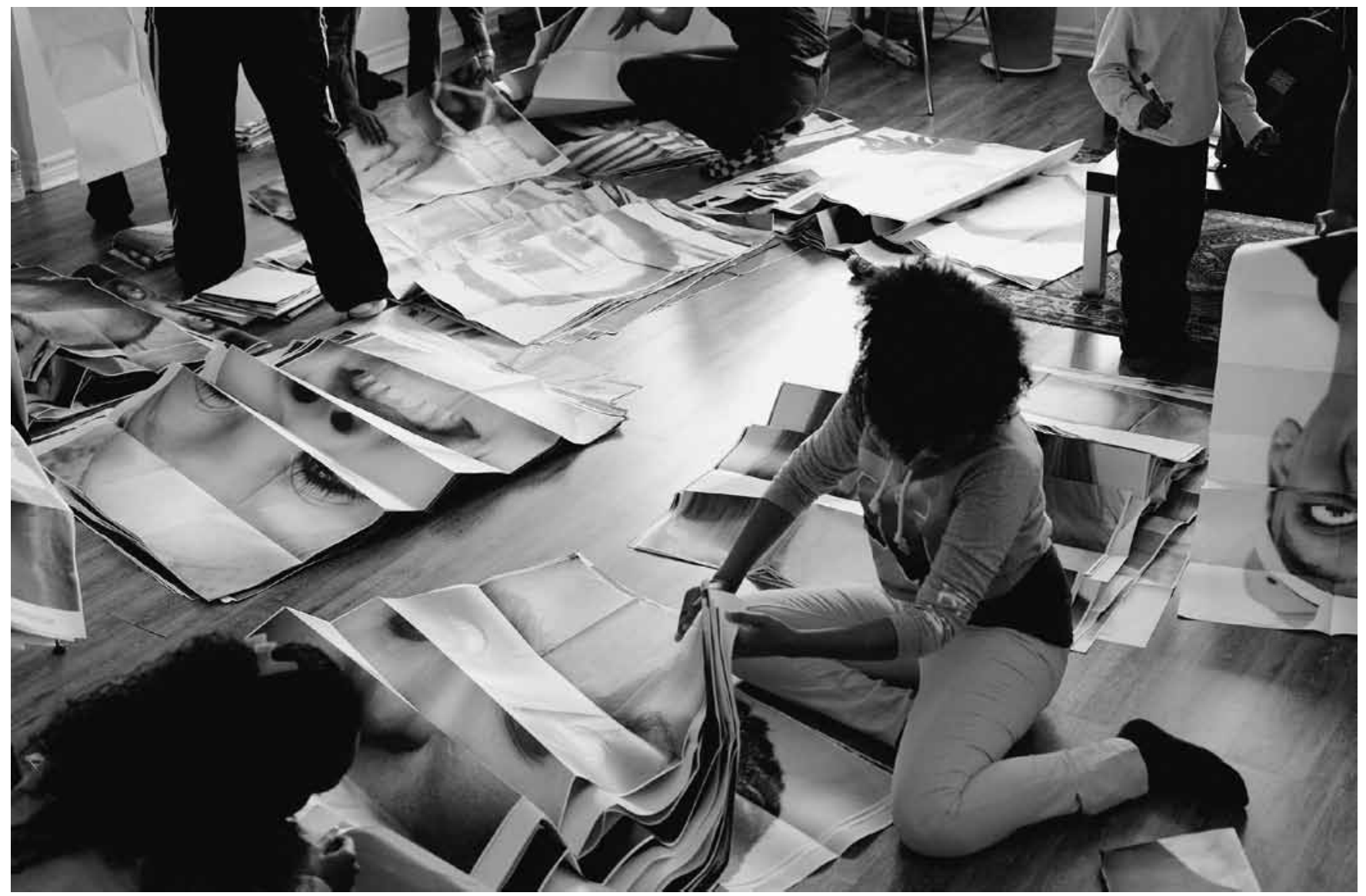

Figure 2. Photo documentation of the Toronto Inside Out group action by Manifesto Festival of Community and Culture, September 20II. Toronto, Ontario (Photo: Anna Keenan, Manifesto Festival, 20II).

mounted in their selected sites (fig. 2).25 At this stage the groups have the task of mounting the posters with or without consent. Groups hoping to paste the posters with consent need to apply for permits in advance or otherwise negotiate with landholders, such as business owners, institutions, or urban developers, to obtain the rights to use the selected space. In addition, many groups plan celebratory events and engage with the press as a way to further spread the message of their project. Thus, there are wide-ranging opportunities for participation within an Inside Out group action, from having one's photograph taken to rather sophisticated, professional tasks, including the management of the action's execution.

The Inside Out website states that anyone may submit photographs. There are, however, a few guidelines that participants must follow. For example, there may be only one subject in an image, and no photographs of animals, objects, or people in disguises that mask their faces. ${ }^{26}$ Portraits must be framed closely around the subject's face and the inclusion of other parts of the body in the image is discouraged. Participants may refer to the "Group Action Guidelines" document, which offers important tips, such as: "The best portraits are expressive, emotional, and captivating. They are more than pictures of smiling faces; they seem to reflect the personality and story behind the face." 27 This document offers a handful of tightly-cropped, black-and-white photographs to serve as examples for prospective participants, including an image of a young man smiling earnestly, a photograph of a child with a huge toothy grin, and a playful portrait of an older gentleman who cheekily sticks out his tongue. Naturally, these guidelines have a significant impact on the final images produced by the groups. While the group actions taking place worldwide are diverse in terms of the subjects, issues, and communities that they represent, they are all meant to share the visual trope of striking, black-and-white portrait posters of diverse individuals that are grouped together in a public space (fig. 3).

It is true that the sites in which the posters are mounted provide context and meaning for the portraits. ${ }^{28}$ However, it is important to note that not all viewers understand this. Mounted 
and left in their various sites, Inside Out portraits often rely on the capacity for the expressive photographic portraits to create an illusion of a "speaking likeness," through which the portraits communicate ideas about the personality of the subjects or even "the individual's relationship to his or her social or political environment." 29 This strategy could present issues since photographic portraits are visual documents that are "fraught with ambiguity," 30 especially when displayed publicly in areas where there may be competing views of identity, community, and place. It is important to establish an ambiguous "space of encounter" - as inspired by JR's practice-in that it raises curiosity and makes viewers responsible for seeking out the stories behind the portraits. ${ }^{31}$ Inside Out participants are nevertheless encouraged to use additional strategies to help communicate their statements and to try to ensure that their messages last.

To better convey their stories and help "share their messages with the world," 32 the Inside Out Project suggests that participants document all the stages of their group action. Each group action is provided a webpage on the Inside Out website where they may display both photo documentation and the collection of portrait photographs amassed for their action. Photographs of group meetings or of people wheatpasting posters help to illustrate that these projects are process-driven and that community collaboration is a critical component to each action (fig. 4). Images of Inside Out group actions can also be found on countless social media, photo sharing, and global media sites. These documentary photographs expand the discursive terrain within which the group action portraits operate and offer a more comprehensive view of what the portraits are intended to signify. 33 Furthermore, documentary photographs of the actions are important considering the ephemerality of Inside Out posters, which are exposed to weather conditions and to interventions by viewers. As JR notes,

When you paste an image, it's just paper and glue. People can tear it, tag on it, or even pee on it—some [posters] are a bit high for that...but the people in the street, they are the curator $[s]$. The rain and the wind will take them off anyway. They are not meant to stay. 34

This is indeed true. As Toronto Star reporter and Inside Out participant Debra Black recalls, her poster lasted only two days before it succumbed to a rainstorm and to the curious fingers of people passing through the alley in which it was posted. 35 In such a short time, Black's poster was reduced to some pieces of the background, a strip of paper representing her long, curly hair, and a part of the Inside Out logo, which is printed on the bottom right-hand corner of each poster. 36 Posters placed in sites of contestation or put up illegally are even more vulnerable, as they may be defaced by dissenters or ripped down by authorities. Sharing photo documentation of the various stages of the

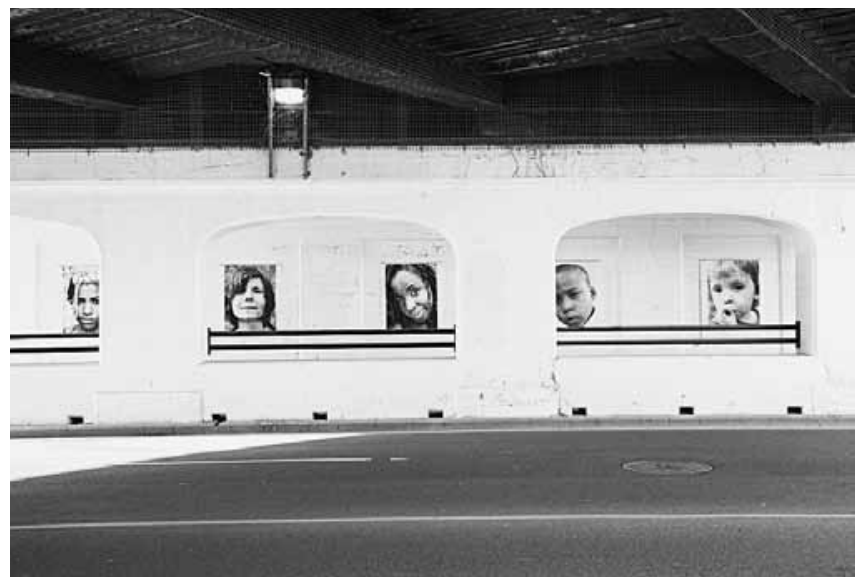

Figure 3. Photo documentation of the Toronto Inside Out group action by Manifesto Festival of Community and Culture, September 201I. Wheatpaste posters, 36" × 53" each. Toronto, Ontario (Photo: Anna Keenan, Manifesto Festival, 20II).

projects online allows for the Inside Out group actions to have what may be seen simultaneously and yet somewhat antithetically as a vital online presence and a digital afterlife.

In addition to the photographic guidelines, there are also stipulations regarding the information presented by and about Inside Out group actions. The website indicates the types of messages that will, or rather will not, be supported by this project. For instance, JR's rejection of branding and corporate sponsorship in his professional work extends to the Inside Out project, and thus the website asserts that groups may not use the project as a vehicle to sell a brand or to promote an institution of any kind. Nor may people use the project to convey messages of "hatred, violence, racism, or extremism," or any other negative sentiment or action that Inside Out essentially seeks to challenge. ${ }^{37}$ Put frankly, prospective participants are told, "Don't be mean,"38 establishing that this project is intended to support messages that are celebratory, optimistic, or otherwise geared toward productive social change. JR also outlines his expectations for the media discourse that surrounds each group action. While he and the TED Conference provide support for group actions, the goal is that these actions will draw attention to the participants and their messages. As a result, press guidelines provide explicit language for participants to use when promoting their projects, which aim to clarify that the message of the group action is their own, and not that of TED or JR.39 Through these guidelines, Inside Out provides a discursive framework in an attempt to avoid subsuming these collective actions into JR's rapidly growing professional portfolio or the TED Conference brand. Thus, the goals and parameters of the project provide a carefully constructed framework that helps to 
guide the process while allowing for flexibility. The potential meanings for the project are seemingly limitless, as the projects proliferate in communities worldwide as well as in the space of the "digital virtual archive," 40 where it is hoped they will continue the dialogues that the group actions were originally intended to inspire.

\section{Cultures of Participation}

If, as scholar Stephen Wright has noted, collaboration "emerges and flourishes under a certain set of circumstances," what are the conditions that have enabled Inside Out to thrive? 41 There are several ways to explain the proliferation of Inside Out, from its association with the ever-growing popularity of street art to its indebtedness to the TED conference media attention, 42 from its significant online presence to its visual impact and important social messages. However, to better understand the overwhelming popularity of the Inside Out Project, we must first situate this practice within the recent, broader cultural shift toward participation.

As a global participatory art project, Inside Out is certainly part of what we have come to know as the "social turn" in the arts, as described in art historian Claire Bishop's 2006 Artforum essay, which she has since readdressed as a "return to the social" in her 2012 publication entitled Artificial Hells.43 Bishop, along with several other scholars, including but by no means limited to, Grant Kester, Gregory Sholette and Blake Stimson, and Okwui Enwezor, have established that while participatory, collaborative, or collective art practices have had longstanding and varied roles in the history of art, new forms of "participatory art" emerged in the 1990s. ${ }^{44}$ There have been several scholarly approaches to defining this surge of participation-based art forms, including Nicolas Bourriaud's theory of "relational art," Suzanne Lacy's writing about "new genre public art," and Grant Kester's conception of "dialogical art." 45 In addition, scholars have referred to the work of a myriad of theorists to describe these participatory art practices, including Walter Benjamin, the Situationist International, Paulo Freire, Deleuze and Guattari, and Hakim Bey, 46 as well as Foucault, Derrida, Agamben, Badiou, and Rancière. ${ }^{47}$ Post-1990s participatory art has been hotly debated in art and humanities scholarship in efforts to understand the divergent goals, values, and outcomes of various participatory art practices and to try to determine the most effective critical approach to these projects. Specifically, scholars have been concerned with how participatory projects challenge traditional (modernist) conceptions of both artists and art objects and raise important questions about ethics and aesthetics in socially engaged art. ${ }^{48}$ Generally speaking, "participatory art" emerges as a broad term that refers to a range of practices that work within the "social field" and often aspire to generate social change. ${ }^{49}$ Inside Out offers just one of many new "ways of being together in contemporary art." 50 By refusing corporate sponsorship, creating ephemeral works, emphasizing the importance of process, and aspiring to engage with community issues, Inside Out uses similar strategies to those of other participatory art practices, in which, as described by Bishop, "artists devis[e] social situations as a dematerialised, anti-market, politically engaged project to carry on the avant-garde call to make a more vital part of life." 51

Inside Out is also fuelled by a growing enthusiasm for participatory photography in a vast range of fields, including social work, health and education studies, and urban planning. These diverse fields follow impulses similar to those of participatory art forms, including the desire to create an active and empowered subject, the interest in decentring the role of the "author" by working collectively, thereby democratizing authorship, and the need to respond to a perceived crisis in "community" through socially engaged collaborative work. 52 As a result, in the past decade there has been a greater presence of participatory projects that aim to put a "human face" on important social issues by using photographs to make authoritative statements about communities worldwide. Through visual research strategies such as Photovoice, community members are recruited to inspire cross-cultural dialogues, to promote social equality in the production of knowledge, and to compose compelling portraits of "community" for local and global audiences. ${ }^{33} \mathrm{JR}$ 's Inside Out Project, which is rooted in community research and social action, and which he has described as "local faces for a local message," 54 is also part of this burgeoning trend that links visual research and photographic practice.

Furthermore, in the last couple of decades we have seen the emergence of a new visual trope that uses collections of portrait photographs in both art and social media to convey messages about identity and community. For example, there has recently been a dramatic increase in the number of participatory art projects that utilize photographic portraiture. In addition to Inside Out, we have also seen the use of portrait photographs to make communities visible in Wendy Ewald's collaborative work with students in Richmond, Virginia (The Carver Portraits, 2005), Tim Van Horn's Canadian Mosaic Project (2007-present), and Pierre Maraval's Portraits x 1000 series (c.1993-2010), to name a few. This is particularly interesting since portrait photography was considered an arguably unpopular artistic genre until the 1970 s or 1980 s. 55 In the art world, the portrait photograph experienced a kind of renaissance through conceptual portrait work by such artists as Braco Dimitrijevic and Cindy Sherman, as well as through what has been called the "big-face photography movement" exemplified by work such as Thomas Ruffs oversize photographic portraits. 56 However, these trends do not entirely explain the rise of ambitious, community-engaged 


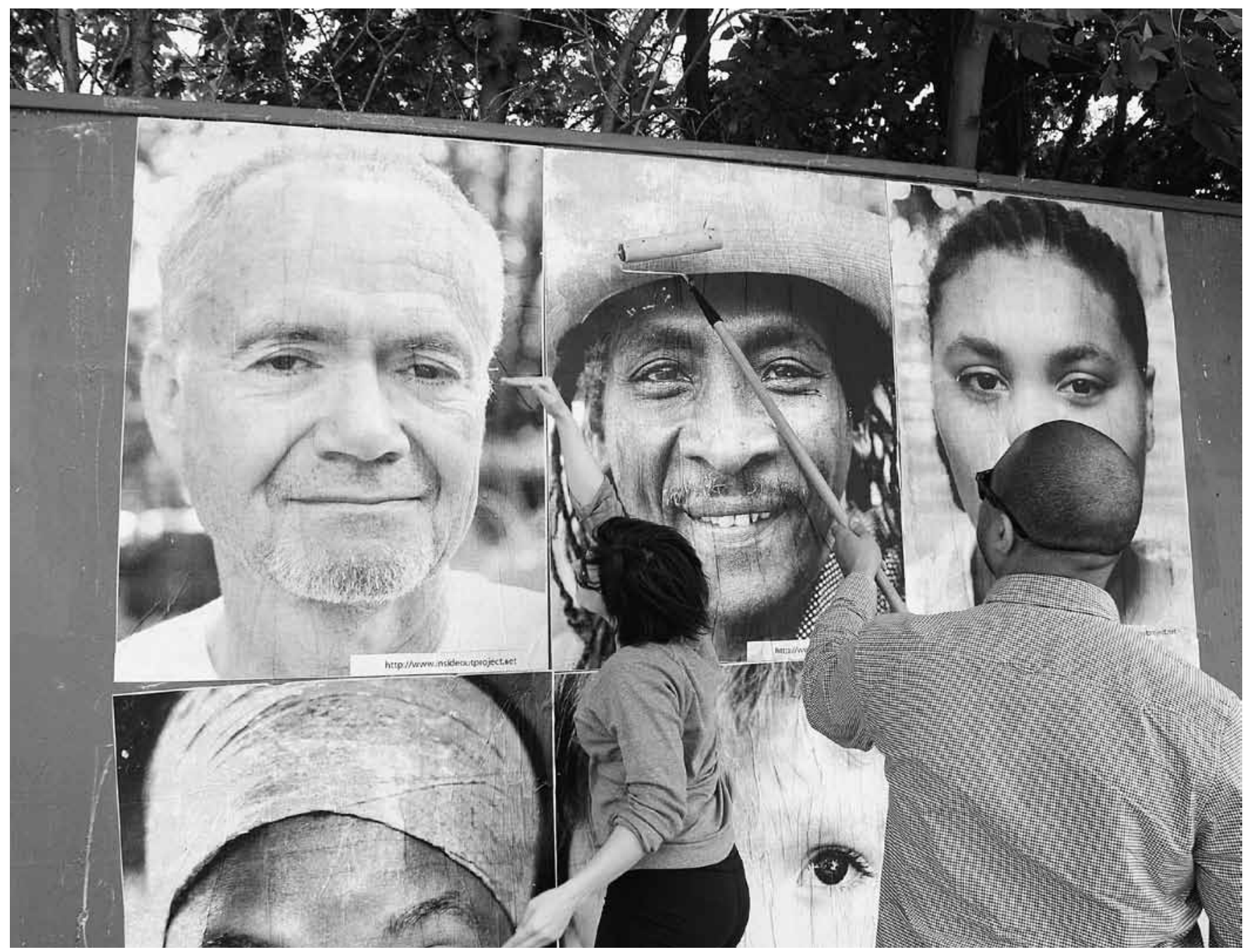

Figure 4. Photo documentation of the Toronto Inside Out group action by Manifesto Festival of Community and Culture, September 20II. Toronto, Ontario (Photo: Anna Keenan, Manifesto Festival, 20II).

portrait projects through Inside Out, some of which are not facilitated by artists.

JR's concept capitalizes on the new roles of portraiture that have emerged in light of social media and social networking technologies. Today photographic portraits have a significant online presence through a variety of social media sites, especially in the form of the "profile photograph" (which is not to be confused with a photograph of one's profile). The "profile photograph" is not always a representation of one's likeness; people use a range of images including photographs of beloved childhood television characters, snapshots of delicious meals, and even sonogram images of babies in utero as their profile photographs to represent different aspects of their lives. However, most often the profile photograph is a thumbnail image of a closely cropped photographic self-portrait. The most conspicuous of this type of image is the "selfie," a self-portrait taken at arm's-length that represents the photographer either alone or closely flanked by other people. These photographs represent our "public face" in the virtual world and are associated with an increasing number of our online interactions. Similar to the various groups of Inside Out portraits, profile photographs also help to visualize the otherwise "imagined communities" with which we identify. 57 As Frieze editor Jennifer Allen argues, the photographic portrait plays a pivotal role in asserting ideas about personal identity through its use in the "daily, if not minuteby-minute, staging of the self" that occurs online. ${ }^{58}$ In the age of online applications such as the Facebook Friend Wheel, Social Graphs, and the Touchbook Facebook Browser, 59 which 
strikingly chart the interpersonal relationships within one's "circle of friends," innovative ways to represent social networks in which we participate are becoming increasingly appealing. The use of photographic portraits to make ourselves visible or to define ourselves to an expanding online community may help to explain the growing demand for, if not the rising level of comfort with, platforms such as Inside Out. ${ }^{60}$ Furthermore, we begin to see how JR's photographic guidelines for the project overlap with suggested guidelines for those seeking advice on how to best represent themselves on social media. A simple online search for "profile photograph" generates countless articles offering similar photographic tips, including, "You should be the only subject in the photo" 61 and "think of a head-andshoulders shot." 62

Numerous scholars have noted how new cultures of participation respond to recent social and political circumstances, and in particular, to those that have arisen out of global neoliberalism. ${ }^{63}$ Importantly, neoliberalism is understood as both a global and a local phenomenon, and more specifically as a "logic of governing that migrates and is selectively taken up in diverse political contexts." 64 There have also been various approaches to defining different stages of neoliberalism to illustrate that it is a "process, [and] not an end-state." 65 For example, geography scholars Jamie Peck and Adam Tickell have identified phases of "roll-back" and "roll-out" neoliberalism; the former is a destructive wave of austerity measures during the 1980s, and the latter is associated with more recent developments of new technologies of government, policies, institutions, and social subjectivities. 66 What interests me here is how this broader political and economic context of global neoliberalism in its various forms has created both a desire and a perceived need for participatory projects such as Inside Out.

While I am not able to sum up the breadth of scholarship that traces the developments of neoliberalism in this article, a basic introduction to some of its characteristics helps to draw some connections between this global phenomenon and JR's global art project. As cultural critic Henry Giroux argues, it is important to understand the multi-faceted nature of neoliberalism, which is an "economic theory and a powerful public pedagogy and cultural politics." 67 In the 1970s, Keynesian economics, a 1930s economic theory founded on the belief that increased governmental social spending and decreased taxes have the potential to stimulate economic growth, was challenged by the economic theory of neoliberalism, as many countries sought to find new strategies to resolve various global economic issues. 68 This form of neoliberalism was loosely based on classical liberal views, such as those expressed in Adam Smith's book, The Wealth of Nations (1776), including the importance of "free" markets and the need to minimize the role of government. ${ }^{69}$ Some writers have described contemporary neoliberalism as
"Adam Smith on steroids" due to the way that the earlier liberal views have been altered to suit the current global economic context. ${ }^{70}$ The main characteristics of neoliberal economic strategy include reduced social spending, increased privatization, and market deregulation. ${ }^{71}$ Neoliberal economic and social policy redistributes resources and capital to the rich-resources that could greatly serve marginalized communities. ${ }^{72}$ For example, in order to lower the taxes on corporations thereby increasing their profits, public services are drastically reduced if not cut completely. 73 Thus, neoliberal political and economic policies widen the gap between "the rich" and "the poor," which further marginalizes communities and creates a need for innovative and accessible ways to replace vital community programs. In addition, as a public pedagogy and cultural politics, neoliberalism promotes a discourse of creativity, flexibility, individualism, entrepreneurialism, and competitiveness, which places the burden of economic success on individual citizens and away from the government. ${ }^{74}$ In this context, culture and civil society also adopt new roles, being employed for everything from reducing crime to spurring on economic growth by helping to brand globally competitive cities. 75 These developments have impacted communities worldwide, albeit in different ways, and as a result have created a growing sense of political engagement that has manifested itself in various forms of resistance and social organization. ${ }^{76}$ It is precisely out of this situation of "peril and opportunity" 77 that cultures of participation, and projects such as Inside Out, emerge.

Through this discussion, it becomes apparent that Inside Out group actions have the potential to capture how thoroughly entwined neoliberalism and its contestations are. Similar to studies that seek to do away with a binary of "local" and "global," much scholarship has also focused on rejecting a binary of neoliberalism and its contestations, thereby decentring the concept of neoliberalism and at the same time identifying how some forms of contestation take up neoliberal strategies. ${ }^{78}$ While few, if any, of the Inside Out projects explicitly indicate a stance that contests or supports neoliberalism, each project produces representations of communities and identities that are deeply entrenched in, or at the very least influenced by, aspects of the ever-shifting neoliberal policies, practices, technologies, and discourse. For example, as communities gather in meetings and workshops, they take on the functions of vital social programs that may have been cut under "roll-back" neoliberalism. As individuals agree to take action, they use a post-Keynesian political strategy that places the responsibility of wellbeing onto individual subjects and make it a strategy for contestation. On one hand, as posters are mounted in urban spaces, they present us with celebrations of diversity, which is a visual and discursive strategy that has been vital to the creative city agendas that emerged in response to neoliberal austerity measures. On the 
other, Inside Out portraits can inspire alternative readings of urban space, 79 which serve to contest neoliberal policies such as cuts to social welfare programs or community displacement due to urban revitalization programs. Furthermore, we may see in the posters' different stages of deterioration an unintended visual effect that alludes to the challenges faced by communities as a result of neoliberalism. As Bishop states, "the neoliberal idea of community doesn't seek to build social relations, but rather to erode them." 80 Finally, as portraits are posted online, Inside Out engages with Internet technologies and user-generated modes of representing the self that have emerged out of neoliberalism. ${ }^{81}$ Arguably, JR's Inside Out Project even mimics the global spread of neoliberalism, as it too is a flexible strategy used worldwide that takes different forms in different political contexts. Inside Out therefore not only taps into emerging cultures of participation, but also harnesses the existing need and desire of communities worldwide to engage with various forms of neoliberal policies and practice.

\section{The Cultural Impact of Inside Out}

There is no doubt that from a quantitative standpoint Inside Out is a wildly successful endeavour, as it has generated tens of thousands of visually stunning and socially engaged group actions. Inside Out provides people with a relatively straightforward and yet at the same time powerful and complex visual strategy for self-representation. In this respect, JR's wish has certainly succeeded. It has made people and their causes more visible both in their local communities and worldwide. Importantly, in addition to offering an exciting forum for participants to respond to their social and political circumstances, Inside Out also enables us to see where global neoliberalism "touches down," 82 and to further explore the entanglement of neoliberalism and its contestations. 83

Admittedly, for a viewer or an outsider to the various group actions, one of the most challenging aspects of determining the cultural impact of Inside Out has to do with the very heart of the project: the participants. What is the cultural impact of the Inside Out Project in the lives of its individual participants? How do we gauge the success of the various projects in terms of effecting social change, or as JR suggested in his TED Talk, changing perceptions? To answer these questions, one must do extensive community research, which might include amassing anecdotal evidence or discovering if the group actions led to tangible social change within the communities. More importantly, as one group action facilitator recently suggested to me, 84 perhaps to truly get a sense of the personal impact of these projects we must find ways to participate in them ourselves.

\section{Acknowledgements}

This research was supported by the Social Sciences and Humanities Research Council, through a SSHRC Joseph-Armand Bombardier Canada Graduate Scholarship. I would like to thank the following people for their helpful feedback on this paper: Dr. Sarah Bassnett, Dr. Lora Senechal Carney, Ersy Contogouris, Christian Morgan, Angèle St-Pierre, Trista Mallory, Farwah Gheewala, and the participants and attendees of the 2013 UAAC Annual Conference "Forming New Identities" panel.

\section{Notes}

1 JR, "My Wish: Use Art to Turn the World Inside Out," TED: Ideas Worth Spreading, 2011, http://www.ted.com/talks/jr_s_ted_prize_ wish_use_art_to_turn_the_world_inside_out (accessed 1 April 2014).

2 TED, "TED Prize," TED: Ideas Worth Spreading, 2014, https:// www.ted.com/participate/ted-prize (accessed 1 April 2014).

3 See for example: JR, "My Wish," 2011. These videos are also accessible via the popular video-sharing website, YouTube, as well as through Netflix, an on-demand video streaming site.

4 TED, "Prize-Winning Wishes," TED: Ideas Worth Spreading, 2014, https://www.ted.com/participate/ted-prize/prize-winningwishes (accessed 1 April 2014).

5 TED, "Prize-Winning Wishes." Earlier versions of the website explained that winners received $\$ 100,000$, but the website now notes that TED Prize winners receive $\$ 1$ million to put toward their wish.

6 JR, "My Wish."

7 Marco Berrebi, "JR-The Biggest Art Gallery," in JR, Marco Berrebi, et al., Women Are Heroes: A Global Art Project (New York, 2009): n.p. There have been several attempts to define JR's style of work. He has been described as a "photograffeur," a term that recognizes his use of photography and street art traditions, and an "artivist," a term that notes his interests in art and activism. For more examples see Bertie Ferdman, "Urban Dramaturgy: The Global Art Project of JR," PAJ: A Journal of Performance and Art 34, 3 (September 2012): 12; Elizabeth Day, "The Street Art of JR," The Guardian: The Observer, 7 March 2010, http://www.theguardian.com/artanddesign $/ 2010 / \mathrm{mar} / 07 / \mathrm{street}$-art-jr-photography (accessed 5 August 2013); and Christian Caujolle, "A Word to the Wise," in Women Are Heroes, n.p.

8 JR, "My Wish."

9 JR, Inside Out: The People's Art Project, 2014, http://www.insideoutproject.net/en (accessed 1 April 2014).

$10 \mathrm{JR}$, Inside Out.

11 The Inside Out website keeps an ongoing tally of all of the portraits, group actions, and project locations associated with this project. As 
of 22 April 2014, the Inside Out website reported that the project had generated 196,565 portraits through 902 group actions and that these projects took place in approximately 112 countries. See: JR, “Explore," Inside Out, 2014, http://www.insideoutproject.net/ en/map (accessed 22 April 2014).

12 Greg Drakes, "Toronto Inside Out Project," Manifesto, 18 September 2011, http://themanifesto.ca/toronto-inside-out-project/ (accessed 25 September 2013).

13 "We Still Exist," Inside Out: The People's Art Project, 2011, http:// www.insideoutproject.net/en/group-actions/usa-north-dakota (accessed 25 September 2013).

14 “Ted X Karachi," Inside Out: The People's Art Project, 2011, http:// www.insideoutproject.net/en/group-actions/pakistan-karachi (accessed 25 September 2013).

15 "Kick Out the Violence," Inside Out: The People's Art Project, 2013, http://www.insideoutproject.net/en/group-actions/angola-luanda (accessed 25 September 2013).

16 "LGBT Rights in Berlin Germany," Inside Out: The People's Art Project, 2011, http://www.insideoutproject.net/fr/group-actions/ germany-berlin (accessed 25 September 2013).

17 "Save the Arctic," Inside Out: The People's Art Project, 2013, http:// www.insideoutproject.net/en/group-actions/north-pole-northpole (accessed 25 September 2013).

18 The "Explore" page of the Inside Out website helps to visualize the saturation of group actions in developed or democratic regions. Ferdman has linked this pattern to the lack of web technology in developing areas and to issues of censorship in non-democratic regions. See Ferdman, "Urban Dramaturgy," 22.

19 See for example Claire Bishop, Artificial Hells: Participatory Art and the Politics of Spectatorship (London, 2012); Blake Stimson and Gregory Sholette, eds., Collectivism after Modernism: The Art of Social Imagination after 1945 (Minneapolis, 2007); and Grant Kester, The One and the Many: Contemporary Collaborative Art in a Global Context (San Diego, 2011).

20 Kester, The One and the Many, 1; 29.

21 Kester, The One and the Many, 5-6.

$22 \mathrm{JR}$, Inside Out.

23 JR, "Participate," Inside Out, http://www.insideoutproject.net/en/ participate (accessed 1 April 2014).

24 JR, "FAQ," Inside Out, http://www.insideoutproject.net/en/faq (accessed 1 April 2014).

25 JR, "FAQ."

26 JR, "Group Action Guidelines," Inside Out, http://www.insideoutproject.net/sites/all/themes/insideout/documents/Group_Action_Guidelines.pdf (accessed 1 April 2014): 6.

27 JR, "Group Action Guidelines," 6.

28 Ferdman, "Urban Dramaturgy," 19.

29 For a description of the "speaking likeness" conveyed by portraits, see Karen Love, "The Bigger Picture: Portraits from Ottawa," Ciel Variable, 1 December 2003, http://cielvariablearchives.org/ $\mathrm{fr} /$ component/content/article/453-the-bigger-picture-portraitsfrom-ottawa.html (accessed 25 September 2013).

30 Graham Clarke, The Portrait in Photography (London, 1997), 4.

31 Berrebi, "JR-The Biggest Art Gallery," n.p.

32 JR, "Group Action Guidelines," 7.

33 For example, see Rosalind Krauss, "Photography's Discursive Spaces: Landscape/View,” Art Journal 42, 4 (Winter 1982): 311-19.

34 JR, "My Wish."

35 Deborah Black, "Changing the World, One Giant Portrait at a Time,” Toronto Star, 27 October 2011. Black's article offers a personal reflection of an earlier individual action. Since this time, Inside Out has changed its focus to solely support group actions.

36 Black, "Changing the World."

37 JR, "Participate."

38 JR, "FAQ."

39 JR, "Press Guidelines for Participation in the Inside Out Project," 2014, http://www.insideoutproject.net/sites/all/themes/insideout/ documents/Press_Guidelines.pdf (accessed 1 April 2014).

40 Ferdman, "Urban Dramaturgy," 19.

41 Stephen Wright, "The Delicate Essence of Artistic Collaboration," Third Text 18, 6 (2004): 533.

42 Ferdman, "Urban Dramaturgy," 12.

43 Ferdman, "Urban Dramaturgy," 15. See also Claire Bishop, "The Social Turn: Collaboration and its Discontents," Artforum 44, 6 (2006): 178-83, and Artificial Hells, 3.

44 See, for example, Bishop, "The Social Turn" and Artificial Hells; Grant H. Kester, Conversation Pieces: Community + Communication in Modern Art (Los Angeles, 2004) and The One and the Many Stimson and Sholette, Collectivism after Modernism; and Okwui Enwezor, "The Production of Space as Artwork: Protocols of Community in the Work of Le Group Amos and Huit Facettes," in Stimson and Sholette, eds., Collectivism after Modernism, 223-51.

45 Kester, Conversation Pieces, 10. See also Suzanne Lacy, Mapping the Terrain: New Genre Public Art (Washington, 1994); Nicolas Bourriaud, Relational Aesthetics, trans. Simon Pleasance and Fronza Woods with Mathieu Copeland (Dijon, 2002); Bishop, "The Social Turn" and Artificial Hells; and Stimson and Sholette, Collectivism after Modernism.

46 Bishop, Artificial Hells, 11.

47 Kester, The One and the Many, 12.

48 Okwui Enwezor, "The Production of Space as Artwork," 223; Bishop, "The Social Turn" and Artificial Hells.

49 Bishop, Artificial Hells, 1; 12-13.

50 Kester, The One and the Many, 2.

51 Bishop, Artificial Hells, 13.

52 Bishop, "Introduction: Viewers as Producers," Participation (Cambridge: MIT Press, 2006): 12.

53 For a seminal text on Photovoice, see Caroline Wang and Mary Ann Burris, "Photovoice: Concept, Methodology, and Use for 
Participatory Needs Assessment," Health Education \& Behavior 24, 3 (June 1997): 369-87.

54 JR, quoted in Black, "Changing the World."

55 Phoebe Hoban, "The Cindy Sherman Effect," ARTnews, 14 February 2012, http://www.artnews.com/2012/02/14/the-cindysherman-effect/ (accessed 25 September 2013).

56 Hoban, "The Cindy Sherman Effect," and Cornelia Lauf, "Braco Dimitrijević and New York in the 1980s: Influences and Coincidences," Braco Dimitrijević, n.d., http://bracodimitrijevic.com/ index.php? $\mathrm{p}=$ pages $\&$ title $=$ Braco-Dimitrijevic-and-New-York-inthe-1980s-Influences-and-Coincidences (accessed 25 September 2013).

57 See Benedict Anderson, Imagined Communities: Reflections on the Origin and Spread of Nationalism (London and New York, 2006), 6; and Louis Kaplan, American Exposures: Photography and Community in the Twentieth Century (Minneapolis, 2005), xviii.

58 Jennifer Allen, "Who, Me? Narcissism is Back in Fashion," Frieze 143 (November-December 2011): http://www.frieze.com/issue/ article/who-me/ (accessed 2 September 2013).

59 Lee Odden, "Six Facebook Search Engine \& Data Visualization Tools," TopRank, 6 August 2010, http://www.toprankblog. com/2010/08/6-facebook-search-engine-data-visualization-tools/ (accessed 25 September 2013).

60 For an interesting article on how Facebook is used as an identity project, see Randall Anderson, "Building the Self on Facebook," Border Crossings 28, 2 (May 2009): 73-75. See also, Ferdman, "Urban Dramaturgy," 19, for a discussion about Inside Out as the "Facebook of art-making" due to its user-generated nature.

61 Vivian Giang, "8 Profile Picture Rules Every Professional Should Follow," 12 November 2013, http://www.businessinsider.com/ rules-for-your-profile-picture-2013-11 (accessed 1 April 2014).

62 “Take a Great Profile Pic," How-To Wiki, 13 October 2013, http:// howto.wired.com/wiki/Take_a_Great_Profile_Pic (accessed 1 April 2014).

63 For examples, see Bishop, Artificial Hells, Kester, The One and the Many, and Stimson and Sholette, Collectivism after Modernism.

64 Aihwa Ong, "Neoliberalism as a mobile technology," Boundary Crossings (2007): 3 .

65 Jamie Peck and Adam Tickell, "Neoliberalizing Space," Antipode 34, 3 (July 2002): 383. See also Lisa Duggan, The Twilight of Equality?: Neoliberalism, Cultural Politics, and the Attack on Democracy (Boston, 2004).

66 Peck and Tickell, "Neoliberalizing Space," 389.

67 Henry Giroux, "The Terror of Neoliberalism: Rethinking the Significance of Cultural Politics," College Literature 32, 1 (Winter 2005): 15 .

68 C. Richard Tindal and Susan Nobes Tindal, Local Government in Canada (Toronto, 2009), 15.

69 Tindal and Tindal, Local Government, x.

70 Tindal and Tindal, Local Government, 17.
71 Tindal and Tindal, Local Government, 17.

72 For discussions of this form of upward redistribution, see: Giroux, "The Terror of Neoliberalism," Duggan, The Twilight of Equality?, and Tindal and Tindal, Local Government.

73 Giroux, "The Terror of Neoliberalism," 2.

74 Helga Leitner, Eric S. Sheppard, Kristin Sziarto, and Anant Maringanti, "Contesting Urban Futures: Decentering Neoliberalism," in Contesting Neoliberalism: Urban Frontiers, ed. Helga Leitner, Jamie Peck, and Eric S. Sheppard (New York, 2007), 2. See also Nikolas Rose, "Governing Advanced Liberal Democracies," Foucault and Political Reason: Liberalism, Neo-liberalism, and Rationalities of Government, ed. Andrew Barry, Thomas Osborne, and Nikolas Rose (London, 1996): 45.

75 Bishop, Artificial Hells, 13-18. See also George Yúdice, The Expediency of Culture: Uses of Culture in the Global Era (Durham, 2003).

76 Kester, The One and the Many, 6.

77 Kester, The One and the Many, 6.

78 Leitner et al., "Contesting Urban Futures," 5-11.

79 Ferdman, Urban Dramaturgy, 13.

80 Bishop, Artificial Hells, 14.

81 Leitner et al., "Contesting Urban Futures," 9.

82 For a discussion of how cities are sites where global neoliberalism "touches down," see Magrit Mayer, "Contesting the Neoliberalization of Urban Governance," in Contesting Neoliberalism, ed. Leitner et al., 93.

83 Leitner et al., "Contesting Urban Futures," 9.

84 Che Kothari (Toronto-based photographer, director, producer, organizer, instigator, and artist; Formerly the Executive Director of Manifesto Festival of Community and Culture), in discussion with the author, 28 January 2014. 